\title{
Mutations in a Regulator Gene Allowing Pseudomonas aeruginosa 8602 to Grow on Butyramide
}

\author{
By JANE E. BROWN AND PATRICIA H. CLARKE \\ Department of Biochemistry, University College, Gower Street, \\ London, WCIE 6BT
}

(Accepted for publication 26 October 1970)

\begin{abstract}
SUMMARY
Mutants of Pseudomonas aeruginosa 8602 were isolated which, unlike the wild-type strain, utilized butyramide as a growth substrate. One group produced amidases with altered substrate specificities, indicating that the mutations may be in the amidase structural gene. The second group of butyramide-utilizing mutants produced wild-type enzyme and were all constitutive. It was concluded that such mutants possessed mutations in an amidase regulator gene which allowed them to synthesize large amounts of amidase in the presence of butyramide.

Induction of amidase synthesis by $N$-acetylacetamide in the wild-type strain was repressed in a competitive manner by butyramide and other amide analogues, e.g. cyanoacetamide. The constitutive mutant CII, which could not utilize butyramide for growth, was subject to severe repression of amidase synthesis by butyramide and cyanoacetamide. The regulator mutants which were able to grow on butyramide were all less sensitive to repression by butyramide. Mutant $\mathrm{CB} 2$, a butyramide-utilizing regulator mutant, was relatively insensitive to repression of amidase synthesis by cyanoacetamide whereas strain в6, a butyramide-utilizing mutant producing an altered enzyme, was as sensitive to repression by cyanoacetamide as its parent strain the constitutive mutant CII. The contribution of mutations in structural and regulator genes to utilization of novel growth substrates is discussed.
\end{abstract}

\section{INTRODUCTION}

Pseudomonas aeruginosa 8602 grows in a minimal medium with acetamide or propionamide as carbon source, but is unable to utilize butyramide for growth. Acetamide and propionamide induce the synthesis of an aliphatic amidase (acylamide amidohydrolase EC 3.5.I.4) which has a high specific activity for the hydrolysis of these two amides. Suspensions of induced bacteria, or cell-free extracts, hydrolyse butyramide at about $2 \%$ of the rate for acetamide. Brown, Brown \& Clarke (1969) isolated mutants which grew well in butyramide and produced an altered amidase (B amidase) with a much higher rate of butyramide hydrolysis than the wild-type A amidase. The parent strain of these B mutants was an amidase magnoconstitutive mutant, strain CII, described by Brammar, Clarke \& Skinner (1967), which produces large amounts of the A amidase in the absence of an amide inducer. It seemed possible that the absence of growth of strain C I I in butyramide medium was due solely to the" low rate of butyramide hydrolysis by the wild-type A amidase produced by this strain. However, the factors determining growth on butyramide proved to be more complex, since other butyramide-utilizing mutants have been isolated which produce wild-type 
A amidase. This second group of mutants are all amidase regulator mutants and it has been found that some of the amidase regulator mutants described previously by Brammar et al. (1967) are also able to utilize butyramide. It was found earlier (Brammar, 1965) that butyramide repressed amidase induction by gratuitous inducers; we have now shown that it may also repress amidase synthesis by constitutive mutants.

\section{METHODS}

Organisms. The parent strain was Pseudomonas aeruginosa 8602. Mutants were isolated by the methods described by Brammar et al. (1967) and Brown et al. (I969). Table I lists the mutant strains used in this investigation.

Media and growth conditions. Mutant strains were lyophilized as soon as possible after isolation and fresh ampoules opened from time to time. Stock cultures were maintained on nutrient agar and subcultured weekly. Minimal salt medium (Brammar \& Clarke, 1964) was used for all growth experiments with the addition of various compounds as carbon or nitrogen sources. Succinate, pyruvate and acetate as sodium salts were added before sterilization by autoclaving. Amides were sterilized by filtration and added aseptically to the sterile basal medium. Solid media contained minimal salt medium with $I \cdot 2 \%(\mathrm{w} / \mathrm{v})$ Oxoid agar no. 3 . The composition of the selective plate media with respect to carbon and nitrogen sources was $(\%, \mathrm{w} / \mathrm{v}): \mathrm{A}$, acetamide, $\mathrm{O} \cdot \mathrm{I}+$ $\left(\mathrm{NH}_{4}\right) \mathrm{SO}_{4}, 0 . \mathrm{I} ; \mathrm{B}$, butyramide, $0 . \mathrm{I}$ or $0.2+\left(\mathrm{NH}_{4}\right) \mathrm{SO}_{4}, 0 . \mathrm{I} ; \mathrm{V}$, valeramide, $0.2+$ $\left(\mathrm{NH}_{4}\right) \mathrm{SO}_{4}, 0 \cdot \mathrm{I} ; \mathrm{S}$, succinate, $\mathrm{I} \cdot \mathrm{O}+\left(\mathrm{NH}_{4}\right)_{2} \mathrm{SO}_{4}, \mathrm{O} \cdot \mathrm{I} ; \mathrm{S} / \mathrm{F}$, succinate, $\mathrm{I} \cdot \mathrm{O}+$ formamide, $0 \cdot 2 ; \mathrm{S} / \mathrm{L}$, succinate, $\mathrm{I} \cdot 0+$ lactamide, $0 \cdot \mathrm{I}$.

Overnight cultures were grown in $5 \mathrm{ml}$. medium in $25 \mathrm{ml}$. screw-cap bottles and in conical flasks of capacity ten times the medium volume. Some experiments on growth rates and differential rates of enzyme synthesis were made with side-arm flasks (100 ml. conical flasks with ro ml. EEL colorimeter tubes. Cultures were shaken at $37^{\circ}$.

Enzyme assays. Amidase activity was routinely measured by the transferase method described by Brammar \& Clarke (1964) with acetamide as substrate. One unit of transferase activity is defined as the amount of enzyme catalysing the formation of I $\mu$ mole acylhydroxamate $/ \mathrm{min}$. under the standard assay conditions. Transferase assays with other amides were done as described below. Hydrolase assays were done by the methods described by Brown et al. (1969).

Measurement of bacterial growth. Bacterial concentration was estimated by measuring the extinction at $670 \mathrm{~nm}$. in a Unicam SP 600 spectrophotometer and then converting the reading to bacterial dry weight by referring to a standard graph. For the experiments with side-arm flasks the bacterial concentration was determined with an EEL colorimeter (Evans Electroselenium Ltd) using a green filter (OGR I).

Measurement of differential rate of amidase synthesis. The culture medium was inoculated with one-twentieth of its volume of an overnight culture grown in the same medium and samples were removed at intervals to determine bacterial growth and amidase activity. In experiments to determine the effect of amides on amidase synthesis the cultures were grown on a shaker at $37^{\circ}$ until they reached the exponential growth phase $\left(E_{670 \mathrm{~nm}}\right.$ about 0.2$)$ and then divided equally into the required number of flasks to which appropriate additions were made, one flask being retained as control.

Cell-free extracts. Preparation of cell-free extracts and starch gel electrophoresis were done by the methods described by Brown et al. (1969). 
Estimations of amides in growth media. Standard curves for acyl hydroxamates were prepared as follows: I ml. of an amide solution containing $50 \mu$ moles amide was heated with $2 \mathrm{ml}$. of $5 \mathrm{M}$-hydroxylamine hydrochloride in $4.5 \mathrm{M}-\mathrm{NaOH}$ in a boiling water bath for $15 \mathrm{~min}$. The solution was cooled, neutralized with $2 \mathrm{M}-\mathrm{HCl}$ and made to $10 \mathrm{ml}$. to give a standard solution containing $5 \mu$ moles acyl hydroxamate $/ \mathrm{ml}$. Aliquots were added to $0.5 \mathrm{ml}$. tris buffer $(0 . \mathrm{I} \mathrm{M}, \mathrm{pH} 7.2)$, the volumes made to I $\mathrm{ml}$. with distilled water and $2 \mathrm{ml}$. ferric chloride reagent added $\left(\mathrm{FeCl}_{3} 6 \%\right.$, w/v, in $\mathrm{HCl}$ $2 \%$, w/v). At $500 \mathrm{~nm}$. an extinction value of $\mathrm{I} \cdot 0$ corresponded to the hydroxamate formed from $3.25 \mu$ moles acetamide, $3.2 \mu$ moles propionamide, and $3.54 \mu$ moles butyramide. For amide estimations I $\mathrm{ml}$. samples were removed from the growth medium and kept frozen until assayed by the above procedure.

Transduction. Phage lysates were prepared from butyramide-utilizing mutants and used to transduce amidase-negative recipients according to the methods described by Brammar et al. (1967).

Reagents. Tris (2-amino-2-hydroxymethylpropane-I : 3 diol) was obtained as 'Trizma base' from the Sigma Chemical Co. Acetamide (Hopkin and Williams, Ltd) was recrystallized twice from ethanol; propionamide and butyramide (British Drug Houses Ltd) were recrystallized twice from ethanol; cyanoacetamide (Koch-Light Ltd) was recrystallized twice from methanol; $N$-acetylacetamide was prepared by refluxing acetamide with excess acetic anhydride, removing the residual acetic anhydride and acetic acid by distillation and twice recrystallizing the product from methyl ethylmethyl ketone. Hydroxylamine hydrochloride (Koch-Light Ltd) was recrystallized twice from ethanol+water $(3+\mathrm{I}, \mathrm{v} / \mathrm{v})$. Analar ferric chloride solution $(60 \%$, w/v) was obtained from Hopkin and Williams, Ltd.

\section{RESULTS}

\section{Isolation and characterization of butyramide-utilizing mutants}

Butyramide-utilizing mutants isolated from strain C I I after treatment with NMG ( $N$-methyl- $N^{\prime}$-nitro- $N$-nitrosoguanidine) have been described previously (Brown et al. I969). These strains (в I to в6) produced amidase differing from that produced by strain CII in both electrophoretic mobility and amide substrate specificity. Other butyramide-utilizing mutants which arose spontaneously from strain C I I appeared to produce the same amidase as the parent strain and these were designated CB I to CB 5 . Further mutants were isolated from colonies which arose spontaneously from the wild-type strain on butyramide agar; these mutants all produced wild-type amidase constitutively and were designated СB 6 to СB I2. Both В and СB mutants took 3 days to reach maximum colony size on butyramide compared with 2 days on acetamide. Various other mutant strains with altered amidase regulation were also tested for growth on butyramide. These included the magnoconstitutive and semiconstitutive strains (C mutants), the formamide-inducible strains (F mutants) isolated by Brammar et al. (1967) and strains in which amidase synthesis showed decreased sensitivity to catabolite repression ( $\mathrm{L}$ mutants). Some of the semiconstitutive as well as some of the magnoconstitutive strains were able to grow on butyramide (Table I). Of the $\mathrm{L}$ mutants, only the two constitutive strains, L9 and LIO, grew on butyramide; the inducible L strains, like the formamide-inducible strains, were unable to do so.

Extracts of all CB strains, those C strains which utilized butyramide and strains 29 
Table I. Growth of mutants of Pseudomonas aeruginosa 8602 on amide selective media

\begin{tabular}{|c|c|c|c|c|c|c|}
\hline \multirow[b]{2}{*}{ Mutant no. } & \multirow[b]{2}{*}{ Parent } & \multirow{2}{*}{$\begin{array}{l}\text { Isolation } \\
\text { medium* }\end{array}$} & \multirow[b]{2}{*}{ Phenotype } & \multicolumn{3}{|c|}{$\begin{array}{l}\text { Relative growth on plates after } \\
3 \text { days at } 37^{\circ *}\end{array}$} \\
\hline & & & & $\mathrm{S} / \mathrm{F}$ & $\mathbf{S} / \mathbf{L}$ & B \\
\hline $\begin{array}{l}\mathrm{B} \text { I to } \mathrm{B} 6 \\
\mathrm{CB} \text { I to } \mathrm{CB} 5 \\
\mathrm{CB} 6 \text { to } \mathrm{CB} \text { I } 2\end{array}$ & $\begin{array}{l}\text { CII } \\
\text { CII } \\
\text { WT } †\end{array}$ & $\begin{array}{l}\text { B } \\
\mathbf{B} \\
\mathbf{B}\end{array}$ & $\begin{array}{l}\text { Magnoconstitutive } \\
\text { Magnoconstitutive } \\
\text { Magnoconstitutive }\end{array}$ & $\begin{array}{l}+++ \\
+++ \\
+++\end{array}$ & $\begin{array}{c}++ \\
-\end{array}$ & $\begin{array}{l}+++ \\
+++ \\
+++\end{array}$ \\
\hline $\begin{array}{l}\mathrm{CI}, \mathrm{C} 8, \mathrm{C} 10, \mathrm{CI} \text { ' } \\
\mathrm{C} 4 \\
\mathrm{CII}, \mathrm{C} 22, \mathrm{C} 24\end{array}$ & $\begin{array}{l}\text { WT } \\
\text { WT } \\
\text { WT }\end{array}$ & $\begin{array}{l}S / F \\
S / F \\
S / F\end{array}$ & $\begin{array}{l}\text { Magnoconstitutive } \\
\text { Magnoconstitutive } \\
\text { Magnoconstitutive }\end{array}$ & $\begin{array}{l}+++ \\
++t \\
++t\end{array}$ & - & $\begin{array}{c}++ \\
+ \\
-\end{array}$ \\
\hline $\begin{array}{l}\mathrm{C} 15, \mathrm{C} 20 \\
\mathrm{C} 2 \\
\mathrm{C} 5 \\
\mathrm{C} 9, \mathrm{C} 17\end{array}$ & $\begin{array}{l}\text { WT } \\
\text { WT } \\
\text { WT } \\
\text { WT }\end{array}$ & $\begin{array}{l}S / F \\
S / F \\
S / F \\
S / F\end{array}$ & $\begin{array}{l}\text { Semiconstitutive } \\
\text { Semiconstitutive } \\
\text { Semiconstitutive } \\
\text { Semiconstitutive }\end{array}$ & $\begin{array}{l}++ \\
++ \\
+++ \\
+++\end{array}$ & $\begin{array}{c}- \\
+\overline{+} \\
-\end{array}$ & $\begin{array}{c}++ \\
+ \\
-\end{array}$ \\
\hline L9, L 10 & WT & $\mathbf{S} / \mathbf{L}$ & Magnoconstitutive & +++ & +++ & +++ \\
\hline $\mathrm{L}_{4}$ to $\mathrm{L} 7, \mathrm{~L}$ II & WT & $\mathbf{S} / \mathbf{L}$ & Inducible & - & +++ & - \\
\hline F I, F 2, F4, F 6 & WT & $\mathbf{S} / \mathbf{F}$ & Inducible & $+t+$ & - & - \\
\hline
\end{tabular}

* $\mathrm{S} / \mathrm{F}=$ Succinate + formamide medium; $\mathrm{S} / \mathrm{L}=$ succinate + lactamide medium; $\mathrm{B}=$ butyramide medium.

$\uparrow W T=$ Wild-type.

Table 2. Relative amidase activities of washed suspensions of constitutive mutants of Pseudomonas aeruginosa 8602 on acetamide, propionamide and butyramide

Washed suspensions were prepared from cultures grown in pyruvate medium and shaken at $37^{\circ}$ for $16 \mathrm{~h}$. Activities of each suspension in the acyl transferase reaction and in the amide hydrolase reaction are expressed relative to those for acetamide arbitrarily set at 100 .

\begin{tabular}{|c|c|c|c|c|c|c|}
\hline \multirow[b]{2}{*}{ Mutant no. } & \multicolumn{3}{|c|}{ Acyl transferase reaction } & \multicolumn{3}{|c|}{ Amide hydrolase reaction } \\
\hline & Acetamide & $\begin{array}{l}\text { Propion- } \\
\text { amide }\end{array}$ & Butyramide & Acetamide & $\begin{array}{l}\text { Propion- } \\
\text { amide }\end{array}$ & Butyramide \\
\hline B I & 100 & $4 I \cdot 3$ & II $\cdot 8$ & 100 & 447 & 33 \\
\hline в 6 & 100 & $47 \cdot 0$ & $12 \cdot 3$ & 100 & 440 & 27 \\
\hline C I I & 100 & $20 \cdot 4$ & Trace* & 100 & 285 & 2 \\
\hline CB I & 100 & $22 \cdot 2$ & Trace & 100 & 266 & 2 \\
\hline CB 6 & 100 & $23 \cdot I$ & Trace & 100 & 300 & 2 \\
\hline Lro & 100 & $21 \cdot 1$ & Trace & 100 & 275 & 2 \\
\hline
\end{tabular}

and L Io gave amidase bands on starch gels with electrophoretic mobility identical to that given by strain $\mathrm{CII}$, indicating that they all produced wild-type A amidase. This was confirmed by examining the substrate profiles for the transferase and hydrolase reactions with washed bacterial suspensions (Table 2). In the transferase reaction, which is used as the routine assay for this enzyme, the B group of mutants, known to produce an altered amidase, had considerable activity with butyramide as substrate; the other mutants gave only trace reactions with butyramide or isobutyramide. In the hydrolase reaction, which is of more direct interest with respect to utilization of butyramide for growth, the B group of mutants hydrolysed butyramide at about $30 \%$ of the rate for acetamide, but the rate for the other mutants was only $2 \%$. The substrate profile for all butyramide-utilizing mutants other than those of the B group was thus like that of the wild-type $\mathrm{A}$ amidase. 
The values for enzyme activity given in Table 2 were obtained by using less than saturating concentrations of butyramide (Brown et al. 1969). When the determinations of transferase profile were repeated with bacterial extracts using $500 \mathrm{mM}$-butyramide as substrate, values of between 0.73 and 0.79 (relative to the arbitrary value of 100 for acetamide) were obtained for strains CB I, СB 6 and CII, which had given only trace reactions with bacterial suspensions; for the B group of mutants the values were only slightly higher than those obtained with bacterial suspensions and ranged from I 2 to 14.

Brammar et al. (1967) showed that the mutations conferring constitutivity or formamide-inducibility of amidase synthesis were $95 \%$ cotransduced with the amidasepositive character and had concluded that the amidase structural gene and an amidase regulator gene were closely linked. In transduction experiments with amidase-negative mutants as recipients and phage lysates of mutants $\mathrm{CB} 6, \mathrm{~L} 9$ and $\mathrm{L}$ IO as donors, it was found in the present work that about $95 \%$ of the amidase-positive transductants had acquired the constitutive phenotype and that all of these had also acquired the ability to grow on butyramide. It was concluded from these results that, whereas the B group of mutants owed their ability to grow on butyramide to mutations in the amidase structural gene, the butyramide-utilizing mutants belonging to groups C, CB and L were enabled to grow on butyramide by mutations in a regulator gene affecting the control of amidase synthesis.

\section{The effect of butyramide on amidase synthesis by constitutive strains}

Many of the constitutive mutants which were unable to grow on butyramide were potentially capable of producing large amounts of amidase although they appeared unable to produce sufficient to allow growth in butyramide medium. It was thought possible that the difference between the constitutive strains able to grow on butyramide and those unable to do so, might be due to butyramide exerting an effect on the rates of amidase synthesis. Strains C I I, L9, L IO and СB 6 were grown overnight in pyruvate medium containing various concentrations of butyramide; it was found that whereas the presence of $0 . I \%(w / v)$ butyramide had little effect on the amidase activities (measured as acetamide transferase) of cultures L $9, \mathrm{~L}$ IO and CB 6, there was no detectable activity in the C I I culture. This lack of amidase activity could not have been due to enzyme inhibition, since it was known that purified enzyme preparations were unaffected by butyramide in the concentration range 5 to $40 \mathrm{~mm}$, and it was concluded that butyramide repressed amidase synthesis by strain $\mathrm{C}$ I I. More detailed experiments showed that the strains which were able to grow on butyramide varied in the degree of resistance which they possessed to butyramide repression. All the strains listed in Table I were tested for growth in a minimal salt medium containing from I mM to I00 mM-butyramide as the sole carbon source. The strains which had been unable to grow on butyramide plates were also unable to grow in these media. A few of the strains which grew on butyramide plates grew in the liquid butyramide media only at the lower concentrations, from IO $\mathrm{mM}$ to $50 \mathrm{mM}$-butyramide; growth of $\mathrm{CB} 6$ was optimal at $25 \mathrm{mM}$; only strains СB 3 and $\mathrm{L} 9$ grew well at $100 \mathrm{mM}$-butyramide and even for these two strains growth was initially slower at the higher concentrations.

\section{Differential rates of amidase synthesis}

The differential rates of amidase synthesis for some of the butyramide-utilizing mutants were compared during exponential growth in minimal medium containing 


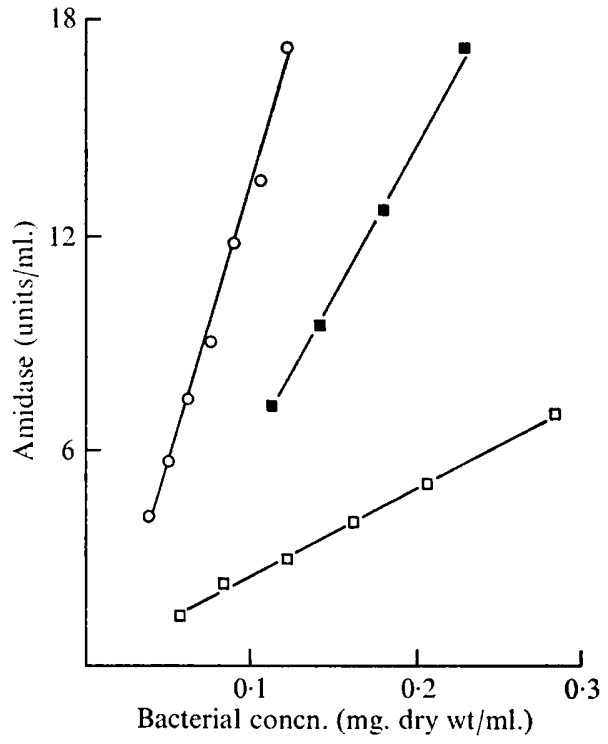

Fig. I

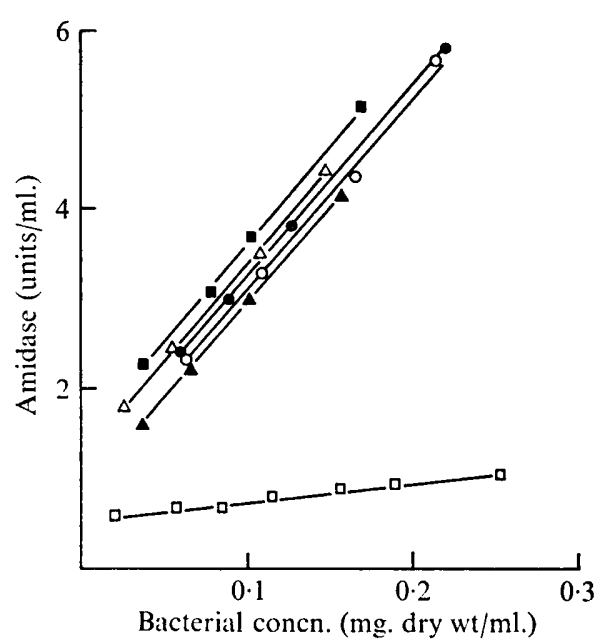

Fig. 2

Fig. ${ }^{1}$. The differential rates of amidase synthesis of strain $\mathrm{L} 10$ growing in minimal medium containing as carbon source, $\mathrm{O}-\mathrm{O}, 40 \mathrm{mM}$ butyramide; $\square-50 \mathrm{~mm}$ pyruvate; $\square-\square, 30 \mathrm{~mm}$ succinate.

Fig. 2. The differential rates of amidase synthesis of $\mathbf{B}$ mutants in minimal medium containing $40 \mathrm{~mm}$-butyramide as carbon source. $\mathrm{-}$, B I ; $\square-\square, \mathbf{B} 2 ; \square-\square$, B 3; $\triangle \longrightarrow \triangle$, в4; $\Delta-\Delta$, в $5 ; 0-1$, в 6 .

Table 3. Differential rates of amidase synthesis of butyramide-utilizing mutants of Pseudomonas aeruginosa 8602

Cultures were grown in side-arm flasks at $37^{\circ}$ with shaking and samples withdrawn at intervals for amidase assay.

\begin{tabular}{|c|c|c|c|}
\hline \multirow[t]{2}{*}{ (1) } & \multicolumn{3}{|c|}{$\begin{array}{l}\text { Differential rates of amidase synthesis } \\
\text { (units/mg. dry wt bacterial mass) }\end{array}$} \\
\hline & \multicolumn{3}{|c|}{ Carbon source for growth } \\
\hline Mutant no. & $\begin{array}{r}\text { Pyruvate } \\
\text { (50 mM) }\end{array}$ & $\begin{array}{l}\text { Succinate } \\
(30 \mathrm{~mm})\end{array}$ & $\begin{array}{l}\text { Butyramide } \\
\text { (40 } \mathrm{mm})\end{array}$ \\
\hline LIO & 84 & 26 & I5I \\
\hline L9 & 55 & 10 & 70 \\
\hline CB 4 & 66 & 8 & 63 \\
\hline CB $6^{*}$ & 40 & 8 & No growth \\
\hline B 6 & 65 & I5 & 22 \\
\hline C II & 56 & 14 & No growth \\
\hline
\end{tabular}

* Strain CB 6 grew in 40 mM-butyramide medium after 48 h.; CB I I does not utilize butyramide.

$30 \mathrm{~mm}$-succinate, $50 \mathrm{~mm}$-pyruvate or $40 \mathrm{~mm}$-butyramide. A pyruvate-grown inoculum was used in each case. Fig. I shows the results for strain L IO and Table 3 gives the rates obtained compared with those for mutants B 6 and C I I. Strain C I I did not grow at all in the butyramide medium. Strain CB 6 did not grow in the butyramide medium during the experimental period, although it grew in this concentration of butyramide 
after $48 \mathrm{~h}$.; this confirmed the earlier experiments which had suggested that it was a mutant still relatively sensitive to butyramide repression. It had been found previously that pyruvate produced the least catabolite repression of all the carbon growth substrates tested; the differential rates of amidase synthesis for strains L 9, L IO and CB 4 growing in $40 \mathrm{~mm}$-butyramide were equal to or greater than those in pyruvate. Mutant B 6 (which produced the altered enzyme) also synthesized amidase in butyramide medium at a moderately high rate and similar rates were obtained with all the other B mutants except B 2 (Fig. 2). Strain B 2 had a very slow rate of amidase synthesis in all media, so the latter result did not appear to be due to specific butyramide repression. Since the altered enzyme produced by the B mutants hydrolysed the butyramide in the medium about 15 times faster than did the A enzyme, the values for the differential rates of amidase synthesis of the B mutants cannot be strictly compared with those of the other mutants listed in Table 3.
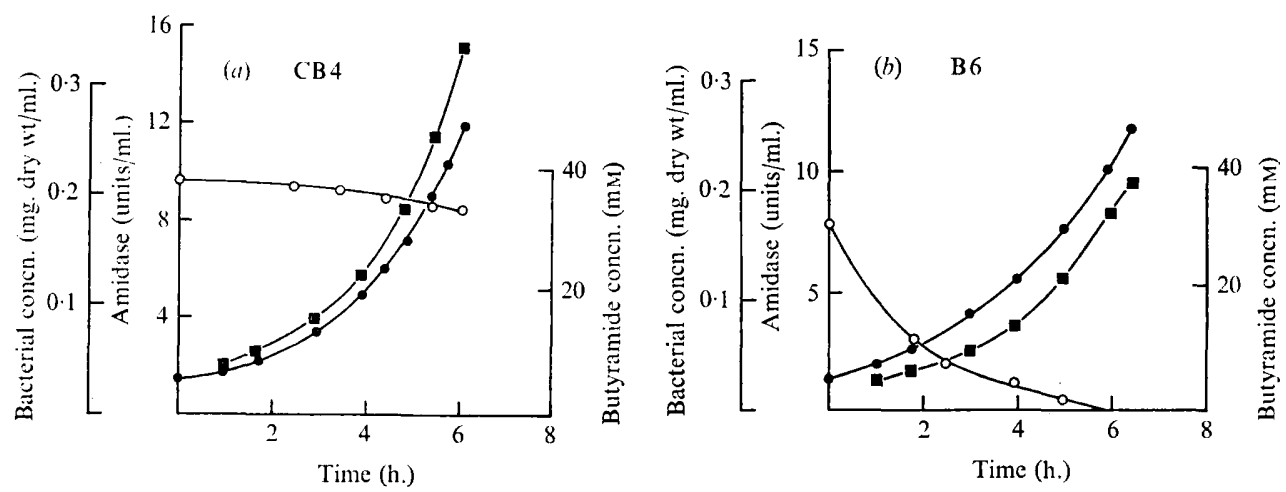

Fig. 3. Growth of butyramide-utilizing mutants in minimal medium containing $40 \mathrm{~mm}$ butyramide as carbon source. (a) Mutant св $4 ;(b)$ mutant в 6 , - -0 , bacterial growth (mg. dry wt $/ \mathrm{ml}$.); $\square-\square$, amidase (units $/ \mathrm{ml}$.); $\bigcirc-\mathrm{O}$, butyramide concentration.

The essential difference between the butyramide-utilizing mutants producing the B amidase and those with regulator mutations was illustrated clearly when the rate of disappearance of butyramide from the culture medium was measured. The two regulator mutants $\mathrm{L} 9$ and CB 4 (A amidase) and mutant B 6 (B amidase) were grown in a minimal medium with $40 \mathrm{mM}$-butyramide as the sole carbon source for growth. The growth rates were similar, but butyramide was hydrolysed much more rapidly by the B 6 culture than by the two regulator mutants although the rate of amidase synthesis was lower (Fig. 3). With L 9 and CB 4 the increase in bacterial concentration was linearly related to the decrease in butyramide and an increase equiv. $200 \mu \mathrm{g}$. dry wt bacteria corresponded to the disappearance of $5 \mu$ moles butyramide. A yield equiv. $200 \mu \mathrm{g}$. dry wt bacteria for complete utilization of $5 \mu$ moles butyramide was also calculated from earlier experiments in which the total growth had been limited by the butyramide concentration in the medium. This suggested that the rate of growth of these two mutants was limited directly by the rate at which they were able to hydrolyse butyramide. In contrast, in the $\mathbf{B} 6$ culture more than half of the butyramide originally present had disappeared with only a small increase in both the total amidase in the culture and the bacterial concentration. For this mutant the amidase activity of the culture in the butyramide medium was not growth-limiting. When a similar experiment was made 
with mutant $\mathrm{L} 9$ growing in acetamide medium all the acetamide disappeared before any increase in bacterial concentration could be detected. The high rate of acetamide hydrolysis by mutant L 9 was greatly in excess of the requirements for growth on acetamide, while the low activity of its amidase towards butyramide limited its rate of growth on that substrate.

\section{Repression by butyramide}

Repression of amidase synthesis was measured quantitatively by adding butyramide to cultures growing exponentially in succinate medium and recording the changes in the differential rates of amidase synthesis. Fig. $4 a$ shows the marked repression resulting from the addition of 20 mM-butyramide to culture of mutant $\mathrm{CII}$. This experiment was repeated with mutants CII, CB 4, CB 6 and $\mathrm{L}$ IO with a range of butyramide concentrations. Each mutant gave a different saturation curve for butyramide repression.
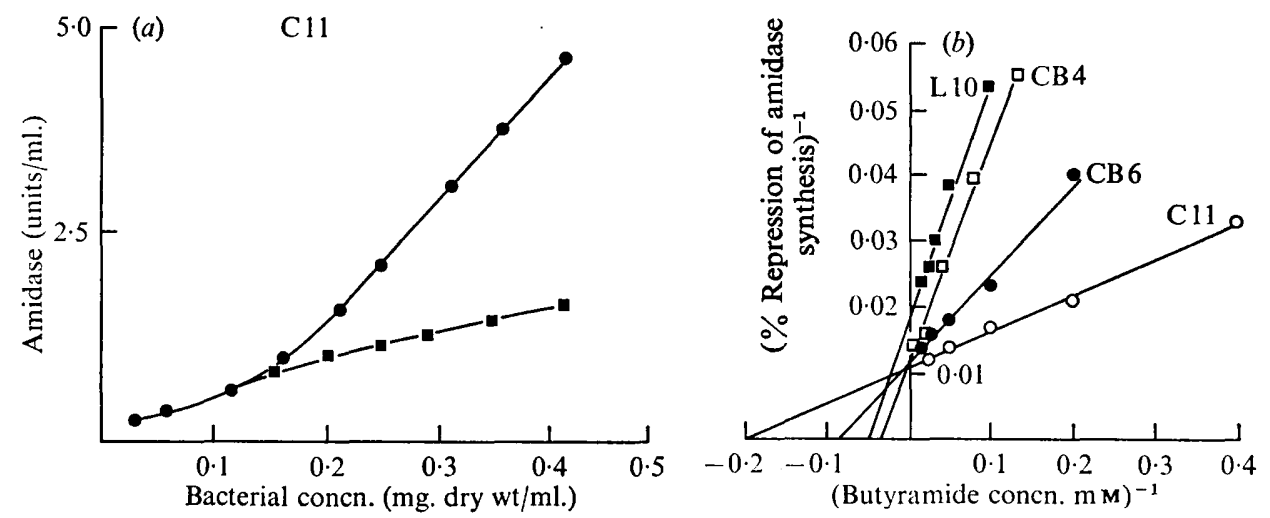

Fig. 4. Repression of amidase synthesis by butyramide. (a) Strain C I I growing exponentially in succinate medium was divided into two parts a bacterial concentration of $0.12 \mathrm{mg}$. dry wt $/ \mathrm{ml}$. - - , Control culture; _-, $20 \mathrm{mm-butyramide} \mathrm{added.} \mathrm{(b)} \mathrm{Mutant} \mathrm{strains}$ growing exponentially in succinate medium were divided into six parts. One was kept as control and various concentrations of butyramide were added to the other five. The differential rates of amidase synthesis were measured and are shown as a double reciprocal plot of percentage repression against butyramide concentration. $\square-\square$, CB 4; $\square-\square, \mathrm{L} 10$.

Strain C I I was severely repressed by low concentrations of butyramide which had little effect on the rate of amidase synthesis by strain $\mathrm{L} I 0$. The maximum repression observed for strain L IO was only about $50 \%$ whereas the repression of the other mutants tended towards $100 \%$ as the butyramide concentration was increased. Double reciprocal plots of the data relating percentage repression of amidase synthesis to butyramide concentration were approximately linear (Fig. $4 b$ ) and these were used to calculate approximate repressor binding constants. The calculated values for $K_{\text {repressor }}$ (the concentration of butyramide giving half maximal repression) were $5 \mathrm{mM}$ for strain CII, I2 mM for strain CB6, $20 \mathrm{mM}$ for strain $\mathrm{L} 10$ and $28 \mathrm{~mm}$ for strain CB 4 . Strain Св6, which grew more slowly in butyramide than the other two butyramideutilizing mutants, and could not grow at all in 75 mM-butyramide, had a much lower repression constant. When similar experiments were carried out with strain $L$ IO in pyruvate medium the maximum repression obtained was again about $50 \%$ and the $K_{\text {repressor }}$ was $18 \mathrm{mM}$, which indicated that butyramide repression was unaffected by concomitant catabolite repression. 


\section{Repression of amidase induction by butyramide}

Brammar \& Clarke (1964) showed that induction of amidase synthesis by acetamide or by the non-substrate inducer $N$-acetylacetamide, was repressed in a competitive manner by cyanoacetamide. This was termed amide analogue repression and it was concluded that cyanoacetamide competed with the amide inducers for an inducerbinding site. With carbon-starved bacteria, in which catabolite repression is minimal, Clarke \& Brammar (1964) determined inducer and repressor constants for amidase synthesis. The values obtained for $K_{\text {inducer }}$ were approximately $0.007 \mathrm{~mm}$ for acetamide and $0.8 \mathrm{~mm}$ for $N$-acetylacetamide. The inhibition constant calculated as $K_{\text {repressor }}$ for the competitive repression of induction by cyanoacetamide was approximately $0.04 \mathrm{mM}$. Butyramide appeared to act in a similar manner in repressing amidase induction by $\mathrm{N}$-acetylacetamide in the wild-type strain in exponentially growing cultures. We have now examined butyramide repression in carbon-starved bacteria with $N$-acetylacetamide as inducer under the conditions used by Clarke \& Brammar (I964). The value obtained for $K_{\text {inducer }}$ for $N$-acetylacetamide was $0.7 \mathrm{mM}$, which agreed well with the previous determination, and the value calculated for $K_{\text {repressor }}$ for butyramide was $0.02 \mathrm{~mm}$. These values would suggest that butyramide has an affinity for the amidebinding site of the same order as that of cyanoacetamide.

Table 4. Repression of amidase synthesis by mutant strains of Pseudomonas aeruginosa 8602

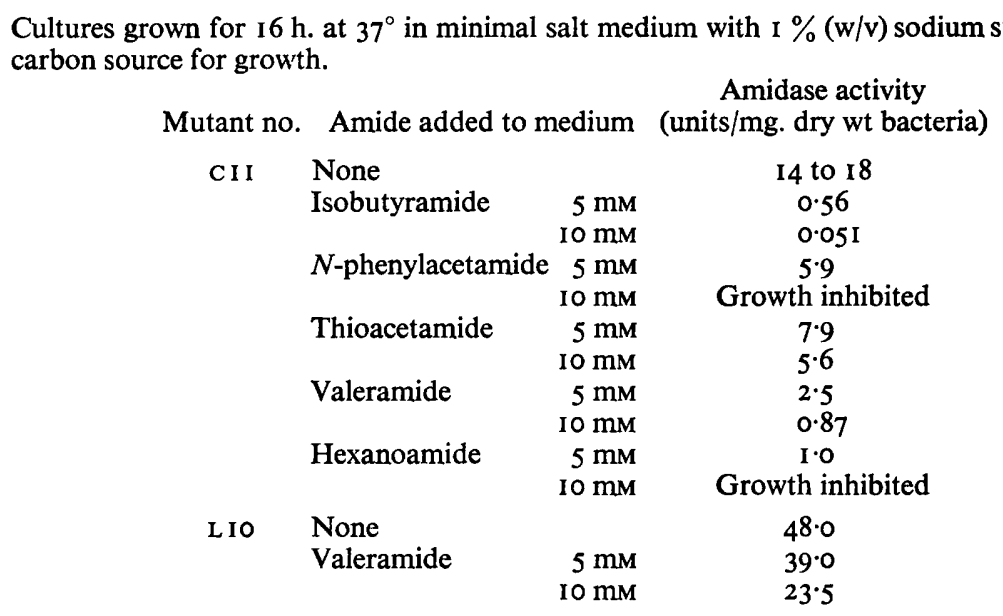

\section{Effect of inducer analogues on constitutive amidase synthesis}

In addition to cyanoacetamide and butyramide, several other amides including $\mathrm{N}$-phenylacetamide, thioacetamide, formamide and hexanoamide have been shown to repress amidase induction in the wild-type strain. Formamide is in fact a very weak inducer but at equimolar concentrations it competes with $N$-acetylacetamide and decreases the rate of amidase synthesis to a very low value (Kelly \& Clarke, 1962; Brammar, I965). Since the constitutive strain CII is very sensitive to repression by butyramide the effect of some of these other amides was tested. Strain C I I was grown overnight in succinate medium in the presence of the amide inducer analogues, none 
of which had significant substrate activity. Table 4 shows that all the amides tested repressed amidase synthesis to some extent. Amidase synthesis under these conditions was not necessary for growth, and the growth inhibition recorded at the higher concentrations of $N$-phenylacetamide and hexanoamide was therefore unrelated to any specific effect on amidase synthesis. It can also be seen that strain L IO, which was less sensitive to butyramide repression than strain $\mathrm{CI} r$, was less sensitive to valeramide repression.

It had been impossible to test whether the B strains, producing the altered enzyme, were as sensitive to butyramide repression as their parent strain C I I since they hydrolysed butyramide too rapidly for the experiment to be done. However, the strains could be compared with respect to their sensitivities to repression by cyanoacetamide, which
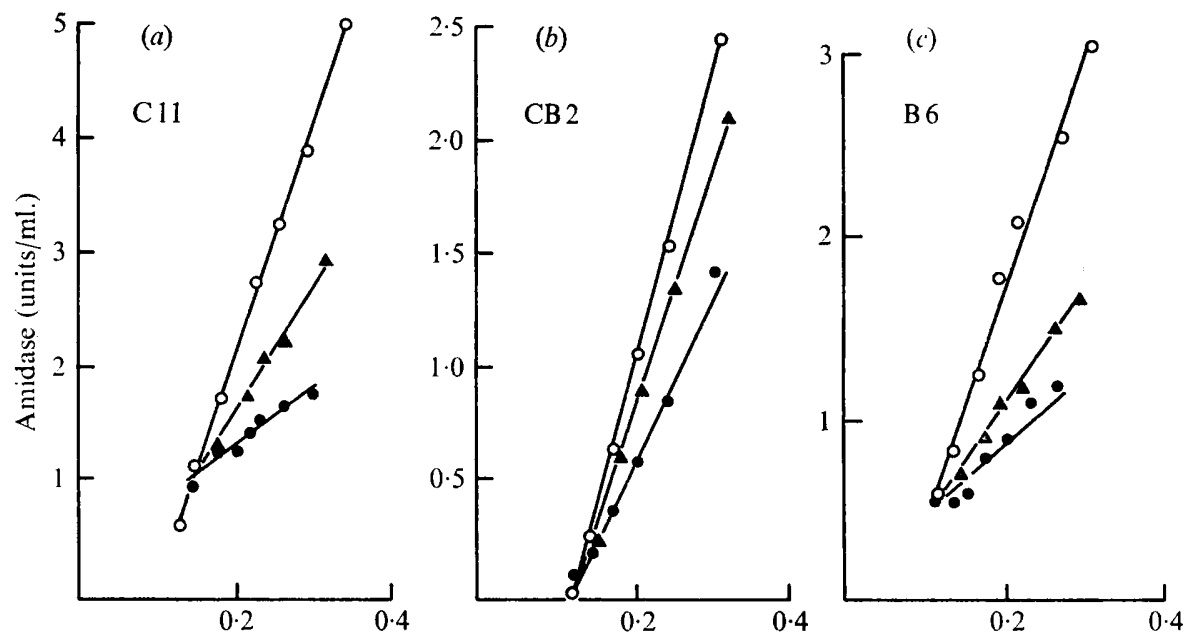

Bacterial concn. (mg. dry wt/ml.)

Fig. 5. Repression of amidase synthesis by cyanoacetamide. (a) Strain C I I (b) strain CB 2; (c) strain B 6. $\bigcirc-\bigcirc$, Control culture; $80 \mathrm{~mm}$ cyanoacetamide added.

was not attacked by any of the strains. Fig. 5 shows the effects of $40 \mathrm{~mm}$ and $80 \mathrm{~mm}-$ cyanoacetamide on amidase synthesis by strains $\mathrm{C}$ I I and $\mathbf{\text { }} 6$ as compared with one of the butyramide regulator mutants both strains were repressed to about the same extent by concentrations of cyanoacetamide which had little effect on the rate of amidase synthesis by strain CB 2 .

It was concluded that the mutation in strain $\mathbf{8} 6$ which allowed growth on butyramide was confined solely to the structural gene for amidase and that the regulator gene was unaffected. The comparison of the effects of the amide inducer analogues on the other butyramide-utilizing mutants indicated that in these strains the mutations in the regulator gene which had reduced the sensitivity to butyramide repression had also altered the regulatory response to the other amides. 


\section{DISCUSSION}

The pseudomonads are well known for biochemical versatility and have evolved complex systems for regulation of enzyme synthesis. Substrates, or occasionally early products, are often inducers of one or more enzymes of a pathway so that the substrate specificities of inducible enzymes may differ from the specificities of their induction systems. The amide substrates are not all inducers of the amidase of Pseudomonas aeruginosa 8602 and the primary reason why the wild-type strain does not grow on butyramide is that the enzyme is not induced by butyramide. The substrate specificity is such that, although the rate of hydrolysis of butyramide is very low as compared with that of acetamide and propionamide, a culture able to produce a sufficient quantity of the amidase would be able to grow on butyramide. We have been able to isolate many constitutive mutants of $P$. aeruginosa 8602 which readily produce so much amidase that under certain conditions it constitutes $5 \%$ or more of the total cell protein. The surprising finding is not that some of the constitutive strains are able to utilize butyramide for growth but that some of them are unable to do so. One could say that in the butyramide-negative constitutive strains, an enzyme which in the wildtype was a typical substrate-inducible enzyme had now become by mutation a 'substrate-repressible' enzyme.

If we consider the ways in which mutation has enabled this organism to grow on a novel carbon source it can be seen that it involved two different routes. The butyramideutilizing mutants described in this investigation all had mutations in a regulator gene which made them constitutive and relatively insensitive to repression by butyramide. Those derived from strain C I I must have had at least two mutations in the regulator gene. On the other hand the B mutants described previously were obtained by two successive mutations in two different genes. The first mutation to constitutivity resulted in strain C I I, too sensitive to repression by butyramide to be able to grow, followed by a second mutation in the amidase structural gene, resulting in an enzyme with altered substrate specificity. This suggests that a threshold degree of enzyme activity, in this case a critical rate of butyramide hydrolysis, was required to enable growth to occur. The butyramide regulator mutants produced a sufficient quantity of the wild-type enzyme to reach this threshold value while the в mutants produced a more efficient enzyme so that in spite of the handicap of butyramide repression they also were able to reach the threshold value for growth. If the amount of amidase synthesized in unit time is expressed as $E$ and the rate of butyramide hydrolysis per enzyme molecule in unit time is $B$ then there is a critical value for $P$ in the equation $E \times B=P$ above which growth can occur. The regulator gene mutations affected the value of $E$ and the structural gene mutations the value of $B$. It would have been theoretically possible for other regulator mutations to have resulted in mutants which were inducible by butyramide and therefore able to grow on butyramide, but so far none has been detected although mutants inducible by formamide were isolated by Brammar et al. (1967).

From the evidence we have obtained previously (Brammar \& Clarke, I964; Brammar et al. 1967) it is reasonable to suggest that the regulation of synthesis of the Pseudomonas aeruginosa amidase is similar to that of the $\beta$-galactosidase of Escherichia coli with a regulator gene of the $i$-type producing a cytoplasmic repressor. However, it has not yet been possible to make cis-trans dominance tests with diploids or to identify an amidase regulator gene product. The wild-type strain can be induced by several amides 
and the inducer specificity is distinct from the substrate specificity. If it be assumed that a cytoplasmic repressor produced by the regulator gene of the wild-type strain is able to bind the inducer (or competitive repressor) amides then our results would suggest that many of the regulator mutants produce cytoplasmic repressors which retain the amide binding site. The repression of constitutive enzyme synthesis by butyramide or cyanoacetamide can then be explained in the same way as induction of the enzyme in the wild-type strain, i.e. as the result of binding of an amide by the specific cytoplasmic repressor.

The cytoplasmic repressor molecules produced by constitutive strains may be considered to have decreased affinities for the operator sites for the structural genes whose transcription they normally control. In the case of the constitutive mutants repressed by butyramide it is possible that amide binding results in a conformational change which increases the affinity of the mutant repressor molecule for the operator site. Alternatively, the repressor amides could stabilize the assembly of mutant cytoplasmic repressor subunits to give a functional repressor, as envisaged by Sadler \& Novick (1965) for temperature-sensitive regulator mutants. Brammar et al. (1967) observed that the magnoconstitutive mutant $\mathrm{C} 24$ was partially repressed by the gratuitous inducer $\mathrm{N}$-acetylacetamide and this effect is probably comparable to the butyramide repression of other constitutive strains. Resistance to butyramide repression could be due to the production of a cytoplasmic repressor which had lost its capacity for binding amides, or had a greatly decreased affinity for the operator even after amide binding, or to the total absence of a cytoplasmic repressor molecule. The mutants derived from strain C I I by the introduction of a second mutation into the regulator gene may have cytoplasmic repressor molecules with amino acid substitutions at both the operator-binding site and the inducer-binding site of the molecule. However, since the functioning of the molecule depends on the total conformation of the repressor protein, and may involve subunit interactions (see Pirrotta, Chadwick \& Ptashne, 1970) the mutations might well have occurred in amino acid sequences not directly concerned with ligand binding.

Repression of enzyme induction by compounds structurally related to inducers is sometimes due to competition for entry into the bacterial cell, e.g. galactose decreases the induction of $\beta$-galactosidase by methyl- $\beta$-D-thiogalactoside (TMG) in Escherichia coli, probably by competition for a specific permease (Llanes \& McFall, 1969). The repression of $\beta$-galactosidase induction with TMG as inducer by 2 -nitrophenyl- $\beta$-Dfucoside (ONPF) on the other hand, appears to be due to competition for the inducer binding site of the cytoplasmic repressor (Müller-Hill, Rickenberg \& Wallenfels, I964). Jayaraman, Müller-Hill \& Rickenberg (I966) found that $\beta$-galactosidase synthesis by certain constitutive $i^{-}$mutants was also repressed by ONPF, suggesting that they produced mutant cytoplasmic repressor molecules which when combined with ONPF became functional in repressing enzyme synthesis. Williams \& Paigen (1968) found that weak inducers repressed $\beta$-galactosidase synthesis in certain $i^{-}$strains but were able to induce operator constitutives and an $i^{t}$ mutant more readily than they induced a wild-type strain. Brammar, McFarlane \& Clarke (I966) showed that cyanoacetamide had no effect on amide uptake by Pseudomonas aeruginosa, so that competition for a permease was not involved. The results now obtained with the various constitutive mutants suggest that all these amide interactions occur with cytoplasmic repressor molecules. 
The regulation of catabolic enzymes by substrate induction allows bacteria to synthesize such enzymes only when they can fulfil a useful metabolic role. Constitutive mutants which are not so constrained may be at a disadvantage in terms of growth rate in media for which the enzyme is not required and this may account for the prevalence of inducible strains in nature. This type of control presents problems in adaptation to growth on new growth substrates. Wu, Lin \& Tanaka (I968) isolated mutants of Klebsiella (Aerobacter) aerogenes which, unlike the wild-type, were able to grow on xylitol. This organism has an inducible ribitol dehydrogenase which has some activity on xylitol, but xylitol is not an inducer so that the primary reason for the absence of growth on xylitol is the regulation of enzyme synthesis rather than the substrate specificity. Mutants, constitutive for ribitol dehydrogenase, were able to grow on xylitol and from these mutants, some faster-growing mutants were isolated which produced an altered enzyme with higher affinity for xylitol as a substrate. Thus both regulator and structural gene mutations were involved in adaptation to a new growth substrate, as in the case of the B mutants of the amidase system.

Mutants of Klebsiella aerogenes able to grow on D-arabinose and L-xylose were isolated which produced constitutively L-fucose isomerase which also acts on Darabinose and L-xylose (Camyre \& Mortlock, I965). If the substrate specificity of an enzyme extends to more compounds than does the inducer specificity then a mutation to constitutivity can allow such mutants to utilize compounds unavailable to the wild-type. During the course of evolution this may have been one of the ways in which new growth characters were acquired. A mutation in a regulator gene could have been followed by a mutation in a structural gene conferring greater activity of the enzyme towards the new growth substrate. Since the constitutive mutation might be accompanied by a lower growth rate a further regulator mutation could result in a return to inducibility, but with a different inducibility profile as well as a different substrate profile from the original parent.

\section{REFERENCES}

Brammar, W. J. (1965). The Control of Amidase Synthesis in Pseudomonas aeruginosa by Induction and Repression Mechanisms. Ph.D. Thesis, University of London.

Brammar, W. J. \& Clarke, P. H. (I964). Induction and repression of Pseudomonas aeruginosa amidase. Journal of General Microbiology 37, 307-319.

Brammar, W. J., Clarke, P. H. \& Skinner, A. J. (1967). Biochemical and genetic studies with regulator mutants of the Pseudomonas aeruginosa 8602 amidase system. Journal of General Microbiology 47, 87-102.

Brammar, W. J., McFarlane, N. D. \& Clarke, P. H. (1966). The uptake of aliphatic amides by Pseudomonas aeruginosa. Journal of General Microbiology 44, 303-309.

Brown, J. E., Brown, P. R. \& Clarke, P. H. (1969). Butyramide-utilizing mutants of Pseudomonas aeruginosa 8602 which produce an amidase with altered substrate specificity. Journal of General Microbiology 57, 273-295.

Camyre, K. P. \& Mortlock, R. P. (1965). Growth of Aerobacter aerogenes on D-arabinose and L-xylose. Journal of Bacteriology 90, 1 I $57-$ I 58.

Clarke, P. H. \& Brammar, W. J. (1964). Regulation of bacterial enzyme synthesis by induction and repression. Nature, London 203, I I 53-I I 55.

Jayaraman, K., Müller-Hill, B. \& RickenberG, H. V. (1966). Inhibition of the synthesis of $\beta$-galactosidase in Escherichia coli by 2-nitrophenyl- $\beta$-D-fucoside. Journal of Molecular Biology, r8, 339-343.

Kelly, M. \& Clarke, P. H. (I962). An inducible amidase produced by a strain of Pseudomonas aeruginosa. Journal of General Microbiology 27, 305-316. 
Llanes, B. \& McFall, E. (1969). Effect of galactose on $\beta$-galactosidase synthesis in Escherichia coli K-1 2. Journal of Bacteriology 97, 217-222.

MüLler-Hill, B., RICKenBerg, H. V. \& WALlenfels, K. (1964). Specificity of the induction of the enzymes of the lac operon in Escherichia coli. Journal of Molecular Biology 10, 303-318.

Pirrotta, V., Chadwick, P. \& Ptashine, M. (1970). Active form of two coliphage repressors. Nature, London 227, 4I-44.

SADLER, J. \& NovicK, A. (1965). The properties of repressor and the kinetics of its action. Journal of Molecular Biology 12, 305-327.

Williams, B. \& Paigen, K. (I968). Paradoxical effect of weak inducers on the lac operon of Escherichia coli. Journal of Bacteriology 96, 1774-1782.

Wu, T. T., Lin, E. C. C. \& TANAKA, S. (I968). Mutants of Aerobacter aerogenes capable of utilizing xylitol as a novel carbon. Journal of Bacteriology 96, 447-456. 